\title{
CAR-T cell i nanotechnologia - najnowsze narzędzia terapii przeciwnowotworowej
}

\author{
Jowita Kwiatkowska, Piotr Wawrzyniak, Agnieszka Knopik-Skrocka \\ Uniwersytet im. Adama Mickiewicza w Poznaniu, Wydziat Biologii, \\ Instytut Biologii Eksperymentalnej, Zakład Biologii Komórki \\ E-mail:jowkwi@st.amu.edu.pl,piowaw@st.amu.edu.pl,askro@amu.edu.pl
}

Stowa kluczowe: terapia przeciwnowotworowa, CAR-T cell, nanotechnologia, nanoczastki

\section{Wprowadzenie}

Zgodnie z najnowszymi danymi, opracowanymi w ramach GLOBOCAN 2020 - the Global Cancer Observatory [1], liczba zachorowań na nowotwory złośliwe na świecie wyniosła w minionym roku prawie 20 milionów. W Polsce, zachorowalność na nowotwory złośliwe to ponad 160 tysięcy przypadków rocznie, z czego odnotowuje się prawie 100 tysięcy zgonów [2]. Dalsze prognozy także nie są optymistyczne. Wysoka śmiertelność wynika zapewne z często późnej diagnostyki, ale także z braku w pełni skutecznej terapii lub braku dostępu do niej. Stosowana od kilku już dziesięcioleci chemioterapia, czy radioterapia wykazują niską selektywność i wiele działań niepożądanych. Wielkim przełomem było zatem opracowanie terapii celowanych na wybrane cele molekularne. Dodatkowo, dzięki coraz większej wiedzy na temat roli mikrośrodowiska nowotworu i jego immunosupresyjnego działania, które umożliwia komórkom nowotworowym ucieczkę spod nadzoru immunologicznego, zmieniło się podejście do leczenia tych chorób i zaczęto opracowywać strategie aktywujące układ immunologiczny pacjenta do walki z nowotworem. Tę grupę terapii określa się mianem immunoterapii (Ryc. 1).

Zaledwie od kilku lat stosowana jest u pacjentów z niektórymi nowotworami hematologicznymi terapia CAR-T, stanowiąca niezwykłe połączenie terapii celowanej z terapią komórkową opartą o limfocyty $\mathrm{T}$ pacjenta, tak zmodyfikowane genetycznie, by rozpoznawały i eliminowały komórki nowotworowe. Modyfikacja ta zachodzi poprzez wprowadzenie do limfocytów $T$ na drodze transfekcji wirusowej informacji genetycznej o CAR, czyli chimerycznym receptorze antygenu (ang. chimeric antygen receptor), który rozpoznaje i wiąże poszukiwany antygen obecny na powierzchni komórek nowotworowych. To, co warto podkreślić - kolejne generacje CAR-T potrafią uwalniać cytokiny pobudzające proliferację komórek immunologicznych pacjenta, a tym samym mobilizują do dalszej walki z chorobą (Dzieńdziura, 2021). 


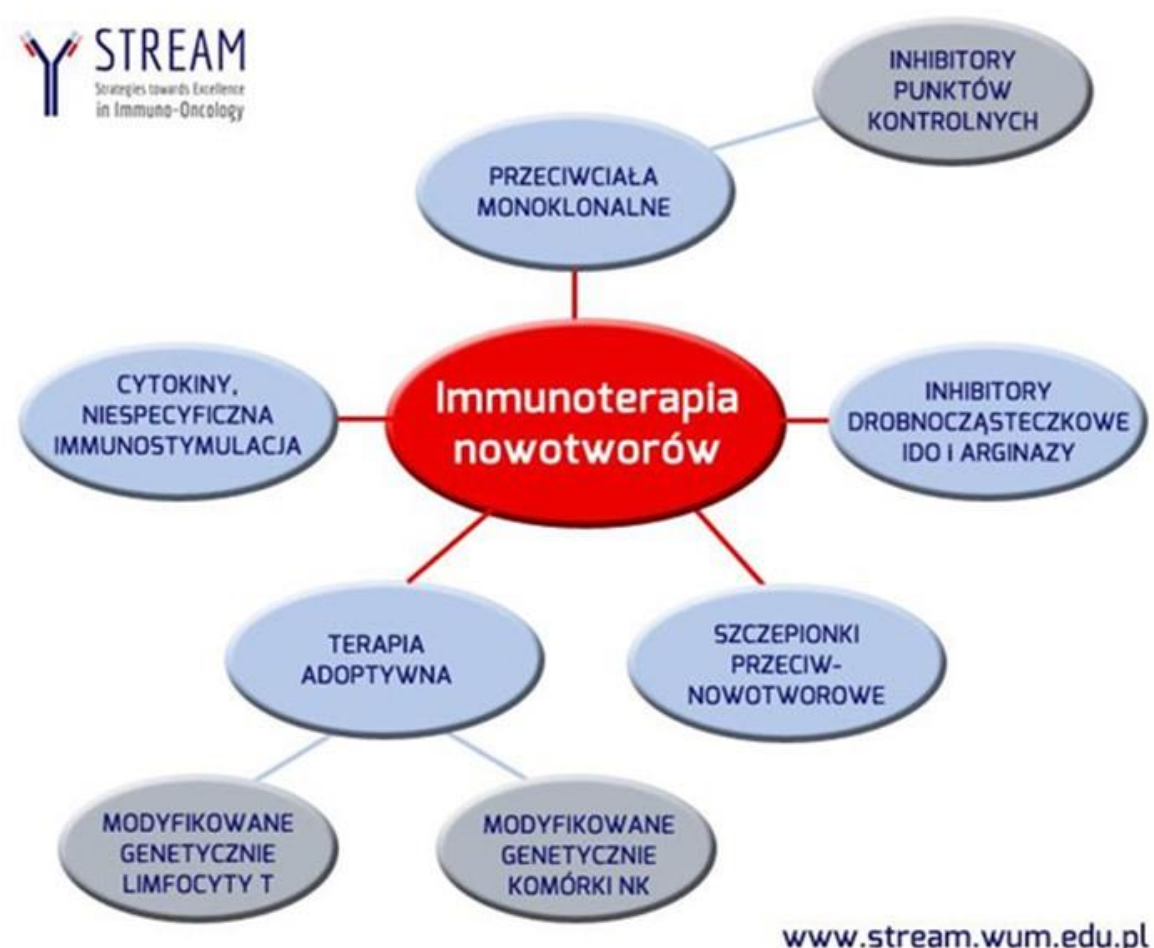

Ryc. 1. Rodzaje immunoterapii nowotworów [3]

W ramach tzw. immunoterapii nowotworów dobre efekty przynosi m.in. terapia za pomocą przeciwciał monoklonalnych blokujących białka tzw. punktów kontrolnych, zlokalizowane na powierzchni komórek immunologicznych oraz komórek nowotworowych. Leki należące do tej grupy działają jako inhibitory punktów kontrolnych. Przykładem są leki blokujące CTLA-4 oraz PD-1 i PD-L1 (Beatty i Gladney, 2015). W tym układzie przeciwciała monoklonalne stanowią precyzyjnie skonstruowaną broń - lek, który rozpoznaje poszukiwany cel, a następnie oddziałuje na niego. W zależności od struktury, przeciwciała monoklonalne mogą być wykorzystane nie tylko jako lek, ale także jako element większego układu transportującego inny lek. Same przeciwciała niosą w tym przypadku informację o adresie, pod który ma zostać dostarczony lek. Przykładem takich układów są nanocząstki opracowywane dzięki zdobyczom nanotechnologii. Chemioterapeutyk jako lek przeciwnowotworowy może zostać zamknięty wewnątrz nanocząstek, wzbogaconych na swojej powierzchni o przeciwciała (Szymanowski i in., 2020). Aktualnie trwają prace nad szeregiem nanocząstek zarówno organicznych, jak i nieorganicznych, które byłyby skutecznymi i bezpiecznymi dla pacjentów nośnikami leków. Podobnie jak receptory CAR w terapii CAR$T$, tak i przeciwciała monoklonalne w połączeniu z nanocząstkami mogą stanowić skuteczne narzędzie do walki z nowotworami.

\section{CAR-T cell - historia, teraźniejszość i przyszłość terapii}

Początek historii opracowania terapii sięga lat 90-tych, kiedy po raz pierwszy udało się w warunkach in vitro uzyskać limfocyty $T$ $z$ tzw. chimerycznym receptorem antygenowym (CAR). Niestety pierwsze limfocyty CAR-T nie były skuteczne klinicznie. Jednak 
pionierskie działania Z. Eshar i G. Grossa z Instytutu Weizmanna w Izraelu stały się kamieniem węgielnym dla dalszego rozwoju terapii, o której do tej pory nie można było nawet marzyć. Dzięki zastosowaniu zdobyczy inżynierii genetycznej stało się możliwe zaprojektowanie i uzyskanie leku bardzo precyzyjnie nakierowanego na cel (Styczyński, 2020). Procedura terapii CAR-T obejmuje kilka zasadniczych etapów, co przedstawia Ryc. 2. Terapia CAR-T stanowi niezwykłe połączenie terapii komórkowej i genowej. Do zdrowych limfocytów T, pozyskanych od pacjenta, wprowadza się bowiem informację genetyczną o CAR, dzięki czemu komórki te będą produkować receptor rozpoznający konkretne antygeny na komórkach nowotworowych. Terapia CAR-T została w swojej pierwotnej odsłonie przygotowana dla pacjentów z wybranymi nowotworami hematologicznymi, takimi jak białaczka, czy chłoniak. W tym przypadku komórki nowotworowe wykazują na swojej powierzchni nadprodukcję antygenu CD19. To on stanowi znak rozpoznawczy i punkt kontaktu z CAR.

PROCEDURA POWSTAWANIA LIMFOCYTÓW CAR-T

\section{POBRANIE KRWI OD PACJENTA I ODSEPAROWANIE LIMFOCYTÓW T} (afereza)

\section{WPROWADZENIE GENU KODUJĄCEGO CAR DO LIMFOCYTÓW T (transfekcja wirusowa)}

\section{Namnożenie limfocytów CAR-T in vitro}

4. Wprowadzenie limfocytów CAR-T do organizmu pacjenta (infuzja)

Ryc. 2. Główne punkty procedury powstawania limfocytów CAR-T

Od momentu kiedy podjęto pierwsze próby uzyskania i wprowadzenia do leczenia leku w postaci limfocytów CAR-T cell minęło ok. 30 lat (Tab. 1.) Mimo wczesnych niepowodzeń udało się dzięki wysiłkom naukowców i lekarzy opracować skuteczną procedurę powstawania komórek CAR-T, a także uzyskać zgodę od Food Drug Administration (FDA) w Stanach Zjednoczonych, czy European Medicine Agency (EMA) na dopuszczenie do leczenia. Nowy potencjalny lek musi przejść pomyślnie wiele etapów badań. Są to najpierw badania przedkliniczne na liniach komórkowych, zwierzętach laboratoryjnych, a następnie kliniczne, prowadzone w wybranych grupach pacjentów. Całość badań nad nowym lekiem to proces długotrwały i bardzo pracochłonny.

$\mathrm{Na}$ przestrzeni lat podejmowano działania związane z udoskonalaniem CAR w zakresie jego aktywności i trwałości. Efektem tego było opracowanie kilku generacji CAR, o stopniowo zmienianej strukturze (Tab. 1, Ryc. 3). Wspólną cechą wszystkich generacji CAR jest układ CD247, jeden z elementów kompleksu CD3 charakterystycznego dla limfocytów T i niezbędnego do rozpoznawania przez nie 
zagrożenia i walki z nim. Począwszy od drugiej generacji pojawiły się tzw. cząsteczki kostymulujące, zwiększające szansę na kontakt limfocytu T z komórką prezentującą antygen. Wymieniona $w$ Tab. 1. generacja TRUCK jest jedną z najbardziej zaawansowanych (komórki CAR-T czwartej generacji). Dzięki wzbogaceniu zmodyfikowanych limfocytów T nie tylko w CAR, ale także w gen dla interleukiny 12 (IL-12), komórki te produkują wymienioną cytokinę, która pobudza proliferację limfocytów pacjenta i cytotoksyczność wobec komórek nowotworowych (Kim i Cho, 2020). Obecnie trwają prace także nad piąta generacją CART, mającą zapewnić wysoką proliferację, ale także trwałość leku.

Tabela 1. Historia terapii CAR-T cell (Styczyński, 2020, zmienione)

\begin{tabular}{|c|l|}
\hline Rok & \multicolumn{1}{c|}{ Etapy rozwoju terapii CAR-T } \\
\hline 1989 & limfocyty T z chimerycznym receptorem antygenowym CAR (in vitro) \\
\hline 1993 & Limfocyty CAR-T pierwszej generacji (nieskuteczne klinicznie) \\
\hline 2002 & $\begin{array}{l}\text { Limfocyty CAR-T pierwszej generacji skuteczne przeciwko PSA (prostate specific antygen) (in vi- } \\
\text { tro) }\end{array}$ \\
\hline 2003 & $\begin{array}{l}\text { Limfocyty CAR-T drugiej generacji przeciwko antygenowi CD19 w białaczce (badania przedkli- } \\
\text { niczne) }\end{array}$ \\
\hline 2011 & $\begin{array}{l}\text { Limfocyty CAR-T rozpoznające antygen CD19 u pacjentów z przewlekłą białaczką limfocytarną } \\
\text { (badania kliniczne) }\end{array}$ \\
\hline 2015 & $\begin{array}{l}\text { Limfocyty CAR-T rozpoznające antygen CD19 u pacjentów z ostrą białaczką limfoblastyczną (ba- } \\
\text { dania kliniczne) }\end{array}$ \\
\hline 2017 & $\begin{array}{l}\text { Limfocyty CAR-T czwartej generacji (TRUCKs) w nowotworach litych (in vitro, badania przedkli- } \\
\text { niczne) } \\
\text { łaczki limfoblastycznej u dzieci i młodych dorosłych }\end{array}$ \\
\hline 2017 & $\begin{array}{l}\text { Limfocyty CART-T rozpoznające antygen CD19 zatwierdzone przez FDA do leczenia chłoniaka } \\
\text { u dorosłych }\end{array}$ \\
\hline $\begin{array}{l}\text { Limfocyty CAR-T rozpoznające antygen CD19 zatwierdzone przez EMA do leczenia w ostrej } \\
\text { białaczce limfoblastycznej u dzieci i młodych dorosłych oraz do leczenia chłoniaka u dorosłych }\end{array}$ \\
\hline
\end{tabular}

FDA - Agencja Żywności i Leków w USA, EMA - Europejska Agencja Leków 


\section{Tutoring Gedanensis}

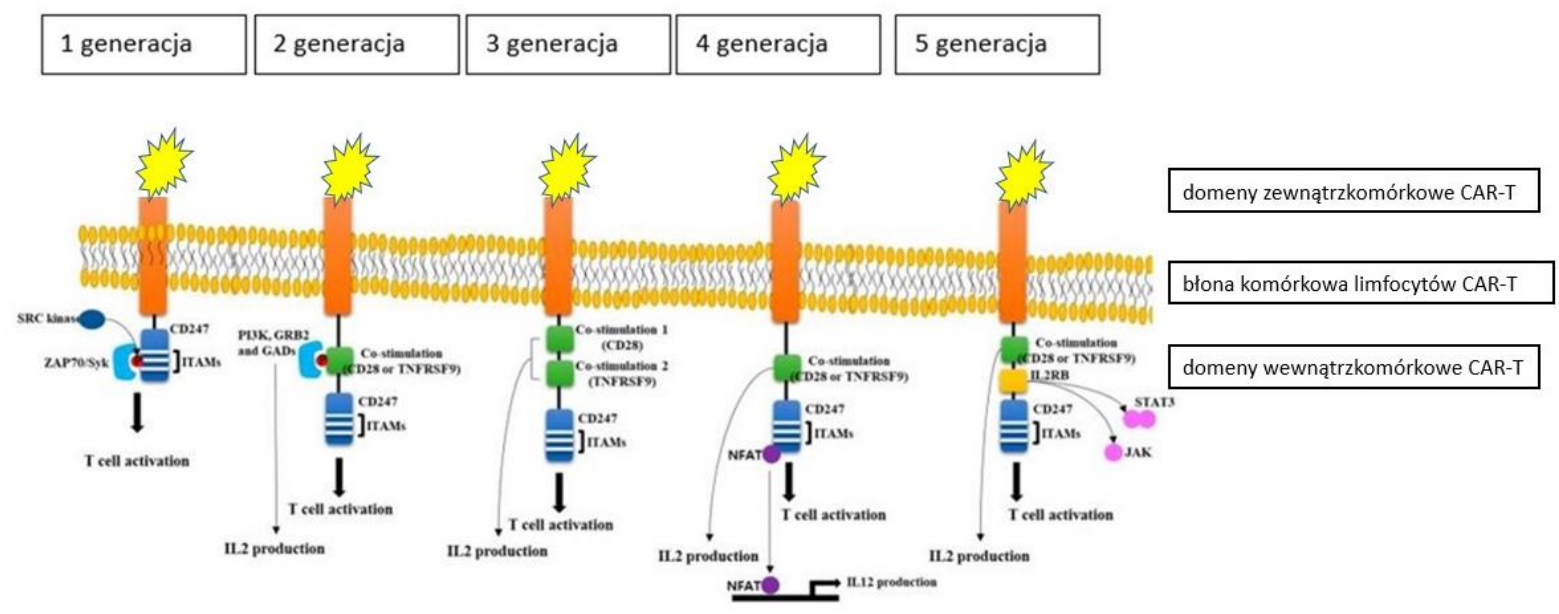

Ryc. 3. Generacje limfocytów CAR-T (Kim i Cho, 2020, zmienione)

Najbardziej zaawansowanym krajem pod względem produkcji i terapii z użyciem CAR-T są Stany Zjednoczone. To tam zostały opracowane i dopuszczone do obrotu przez FDA pierwsze leki znane pod nazwą handlową Kymriah i Yescarta (Tab. 2). Pierwszą pacjentką, u której stwierdzono remisję choroby po jednorazowym podaniu Kymriah była wówczas 7-letnia Emily Whitehead z ostrą białaczką limfoblastyczną, oporną na inne terapie. Terapia została zaaplikowana w 2012 roku, a więc jeszcze przed zatwierdzeniem leku do obrotu. Dziewczynka została bowiem włączona do badań klinicznych. Mimo, iż u dziewczynki zaraz po terapii wystąpiło wiele działań niepożądanych, takich jak gorączka, zespół uwalniania cytokin prozapalnych, to obecnie jest w pełni zdrową osobą, bez nawrotu białaczki. W oparciu o wyniki amerykańskich badań klinicznych, w ślad za FDA, zgodę na stosowanie Kymriah i Yescarta wydała także EMA. W 20 krajach Unii Europejskiej terapia jest refundowana, co ma kolosalne znaczenie w przypadku dostępności leków dla pacjentów. Ponadto w Europie znajduje się obecnie kilka laboratoriów mających uprawnienia do modyfikowania limfocytów T.

Tabela 2. Obecnie stosowane limfocyty CAR-T rozpoznające antygen CD19 u pacjentów z białaczką lub chłoniakiem (Styczyński 2020, zmienione)

\begin{tabular}{|l|l|l|}
\hline Data/Instytucja zatwierdzenia & \multicolumn{1}{|c|}{ Nazwa leku } & \multicolumn{1}{|c|}{ Badania kliniczne } \\
\hline 30 sierpnia 2017 (FDA) & Tisagenlecleucel (Kymriah, Novartis) & ELIANA \\
\hline 18 paździemika 2017 (FDA) & $\begin{array}{l}\text { Axicabtagene Ciloleucel (Yescarta, Gilead- } \\
\text { Kite) }\end{array}$ & ZUMA-1 \\
\hline 28 czerwca 2018 (EMA) & $\begin{array}{l}\text { Tisagenlecleucel (Kymriah, Novartis), Axi- } \\
\text { cabtagene Ciloleucel (Yescarta, Gilead-Kite) }\end{array}$ & ELIANA, ZUMA-1 \\
\hline
\end{tabular}

FDA - Agencja Żywności i Leków w USA, EMA - Europejska Agencja Leków 
Niezwykłe w tej terapii jest to, iż wystarczy jedno podanie leku pacjentowi, by doszło do remisji choroby. Jednak terapia jednego pacjenta kosztuje ponad $1 \mathrm{mln}$ złotych. Wysokie koszty wynikają głównie z faktu, iż limfocyty T pobrane od pacjenta są wysyłane do zagranicznego laboratorium i tam poddawane modyfikacjom genetycznym. Procedura przygotowania leku, jego przechowania, a następnie zaaplikowania pacjentowi jest bardzo złożona i rygorystyczna (Dzieńdziura, 2021). Polska należy do tych krajów, które mogą leczyć pacjentów wybranych nowotworów krwi, jednak bez refundacji [4]. Leczenie CAR-T cell może odbywać się zatem jedynie na drodze darowizny leku przez jego producenta lub z funduszy, jakie udaje się uzbierać $w$ ramach działających fundacji wspierających chorych.

W Polsce istnieje kilka ośrodków, które uzyskały stosowną akredytację i mogą pobierać od pacjentów limfocyty T, wysyłać do wskazanych laboratoriów na świecie, a następnie podawać chorym gotowy preparat. Są nimi: Klinika Hematologii i Transplantacji Szpiku Uniwersytetu Medycznego w Poznaniu, Klinika Transplantacji Szpiku i Onkohematologii, Narodowy Instytut Onkologii im. Marii Skłodowskiej-Curie w Gliwicach, Klinika Transplantacji Szpiku, Onkologii i Hematologii Dziecięcej "Przylądek Nadziei” Uniwersyteckiego Szpitala Klinicznego we Wrocławiu. Łącznie w Polsce do tej pory terapię CAR-T zaaplikowano kilku pacjentom.

Pierwszym polskim pacjentem, u którego zastosowano tę terapię był 24-letni mężczyzna z chłoniakiem, leczony w Klinice Hematologii i Transplantacji Szpiku Uniwersytetu Medycznego w Poznaniu. Wcześniejsza transplantacja szpiku nie przyniosła efektów. 25 października 2019 roku zespół pod kierunkiem prof. dr hab. n. med. Lidii Gil, pobrał od pacjenta limfocyty $T \mathrm{i}$ wysłał do laboratorium w USA. Gotowy preparat Yescarta został zaaplikowany pacjentowi 28 listopada
2019 roku (Dytfeld i in., 2020). Nie zaobserwowano u niego żadnych groźnych skutków ubocznych terapii. Jeśli jednak takie się pojawiają, lekarze potrafią nad nimi zapanować. Zostały opracowane dokładne rekomendacje postępowania, zarówno w przypadku skutków związanych z zespołem uwalniania cytokin prozapalnych, jak i skutków neurologicznych (Gil i in., 2020).

O tym, jak wielkie nadzieje medycyna pokłada w terapii CAR-T, świadczą ciągle prowadzone badania, nie tylko nad udoskonalaniem struktury CAR-T, ale także jego aplikacji u pacjentów z nowotworami litymi (Tahmasebi i in., 2019; Marofi i in., 2021). W przypadku nowotworów niehematologicznych ogromnym wyzwaniem jest mikrośrodowisko guza nowotworowego, w którym obok komórek nowotworowych obecnych jest wiele innych, jak np. fibroblasty, makrofagi, limfocyty $T$ regulatorowe. Wiele $z$ nich podlega tzw. rekrutacji. Zrekrutowane komórki wykazują działanie pronowotworowe, czego efektem jest m.in. uruchomienie angiogenezy nowotworowej (powstawanie naczyń krwionośnych okołonowotworowych) i metastaza (Knopik-Skrocka i in., 2017). W kontekście terapii CAR-T dąży się do skonstruowania CAR w taki sposób, aby mogły działać na najbardziej newralgiczne punkty w nowotworze - na komórki nowotworowe, ale także wybrane cele molekularne mikrośrodowiska. Aktualnie trwa wiele badań klinicznych (faza 1 lub 2 badań klinicznych) nad bezpieczeństwem i aktywnością limfocytów CAR-T w raku jajnika, płuc, wątroby, trzustki, piersi, czy czerniaku (Marofi i in., 2021), w których CAR-T są skierowane na antygeny bądź receptory powierzchniowe specyficzne dla danego typu komórek nowotworowych (Tab. 3). Na etapie badań przedklinicznych są prace z wykorzystaniem komórek CAR-T przeciwko zrekrutowanym fibroblastom, makrofagom, limfocytom $T$ re- 
gulatorowym (Tahmasebi i in., 2019; Rodriguez-Garcia i in., 2020). Zatem terapia CAR$T$ w nowotworach litych to dopiero przyszłość, choć miejmy nadzieję, że nie odległa.

Zgodnie z danymi Agencji Badań Medycznych Polska ma szansę znaleźć się w gronie tych państw, w których leczenie CAR-T cell będzie zdecydowanie bardziej rozpowszechnione. Agencja postanowiła przeznaczyć $100 \mathrm{mln}$ złotych na badania mające na celu przygotowanie i wdrożenie technologii CAR-T cell w polskich laboratoriach, co zdecydowanie obniży koszty terapii i skróci czas oczekiwania na leki [5]. 7 grudnia 2020 roku, po zakończonym konkursie, Agencja Badań Medycznych przyznała grant konsorcjum składającego się z kilku polskich ośrodków medycznych z Warszawskim Uniwersytetem Medycznym na czele. W ciągu najbliższych lat konsorcjum będzie realizować projekt pt: „Polish Chimeric Antigen Receptor T-cell Network". W ramach projektu podjęte zostaną także badania kliniczne nad możliwością zastosowania terapii nie tylko w nowotworach, ale także w chorobach autoimmunologicznych, czy neurodegeneracyjnych [6]. Ogromny sukces, jaki odniosła terapia CAR-T w leczeniu niektórych białaczek i chłoniaków, spowodował wielkie zainteresowanie terapią także $w$ innych obszarach medycyny. Jest to terapia spersonalizowana, celowana, którą prof. Lidia Gil podczas swojego wykładu wygłoszonego na tegorocznej Międzynarodowej Konferencji Współczesnej Onkologii nazwała terapią niezwykłą z punktu widzenia intelektualnego, która zawładnęła naukowcami i lekarzami [7].

Tab.3. Przykłady antygenów/receptorów, wobec których prowadzone są badania kliniczne nad zastosowaniem terapii CAR-T w nowotworach litych (Marofi i in., 2021, zmodyfikowane)

\begin{tabular}{|l|l|l|l|}
\hline \multicolumn{1}{|c|}{ Antygen/Receptor } & \multicolumn{1}{|c|}{ Nowotwór-lokalizacja } & Faza badań klinicznych & \multicolumn{1}{c|}{ Numer badania } \\
\hline AFP & wątroba & 1 & NCT03349255 \\
\hline CEA & $\begin{array}{l}\text { płuco, jelito grube, pierś, } \\
\text { trzustka }\end{array}$ & 1 & NCT02349724 \\
\hline EGFR & płuco, wątroba, żołądek & $1 / 2$ & $\begin{array}{l}\text { NCT03179007, } \\
\text { NCT03525782 }\end{array}$ \\
\hline HER-2 & mózg & 1 & NCT03500991 \\
\hline Mezotelina & jajnik, trzustka, płuco & $1 / 2$ & NCT01583686 \\
\hline VEGFR2 & czerniak, mózg & 1 & NCT01218867 \\
\hline
\end{tabular}

AFP - alfa fetoproteina, CEA - antygen rakowo-płodowy, EGFR - receptor czynnika wzrostu naskórka, HER-2 - receptor ludzkiego naskórkowego czynnika wzrostu, VEGFR-2 - receptor czynnika wzrostu śródbłonka naczyniowego 
Nanocząstki organiczne i nieorganiczne jako nośniki leków

Termin nanotechnologia został po raz pierwszy użyty w 1974 roku. 15 lat wcześniej, R. Feynman, nazywany także ojcem nanotechnologii, wypowiedział słynne słowa: "There's plenty of room at the bottom", co tłumacząc mniej więcej oznacza "Jest dużo miejsca na dole" i odnosi się do obiektów o średnicy nie przekraczającej 100 nm (Bayda i in., 2020). Dziś z perspektywy wielu lat możemy stwierdzić, iż Feynman był wizjonerem, a pomysł na wykorzystanie przestrzeni w skali nano- stał się bazą do opracowania nanonośników dla leków. Pierwszymi nośnikami stały się układy organiczne - liposomy. Jednak ze względu na skutki uboczne ich stosowania zaczęto poszukiwać innych (np. micelle polimerowe). Ostatnie lata charakteryzują intensywne badania $w$ tej dziedzinie, szczególnie nad dendrymerami. Wśród nanocząstek nieorganicznych duże nadzieje wiąże się z układami na bazie złota, czy miedzi.

\section{Nanocząstki organiczne}

Liposomy i micele polimerowe

Pierwsze wzmianki o liposomach jako sferycznych strukturach powstających w wyniku spontanicznej samoasocjacji lipidów w określonych warunkach pojawiły się na początku lat 60-tych XX wieku (Banerjee i in., 2015). Wyróżnia się wiele kategorii liposomów, zarówno pod względem ich wielkości, jak i sposobu pozyskiwania. Na przykład SUV (ang. small unilamellar vesicles) wykazują średnicę ok. 20-50 nm i mają postać pęcherzyków wypełnionych wodnym roztworem i otoczonych pojedynczą warstwą lipidową. Liczba tych warstw w większych liposomach może przekraczać 20. W centralnej części zlokalizowany jest lek. Chemioterapeutyk uwalnia się dzięki niskiemu pH w środowisku nowotworów. Liposomy najczęściej stosuje się do leczenia nowotworów piersi, jajnika, mięsaka Kaposiego, czy szpiczaka mnogiego i wykorzystuje się przy tym leki z grupy antracyklin, takie jak doksorubicyna (Błaszczak-Świątkiewicz i in., 2013). Wśród korzyści, jakie niesie ze sobą stosowanie liposomów w dostarczaniu leków, można wyróżnić regulowaną i selektywną biodystrybucję liposomów i ich cargo do komórek, możliwość transportu zarówno leków hydrofilowych, jak i hydrofobowych (Banerjee i in., 2015). Koszt produkcji liposomów jest jednak relatywnie wysoki, ich lipidy mogą ulegać oksydacji, wreszcie wykazują niestabilność fizyko-chemiczną (agregacja, sedymentacja) (Sen i Mandal, 2013).

Micele polimerowe to nanocząstki amfifilowe, czyli posiadające hydrofobowy rdzeń (wnętrze) oraz hydrofilową otoczkę. Rdzeń ma za zadanie gromadzić lek, a otoczka powoduje rozpuszczanie się polimerów w wodzie (Szymanowski i in., 2020). Micelle charakteryzują się wysoką stabilnością in vitro i in vivo oraz możliwością rozpuszczania słabo rozpuszczalnych farmaceutyków. Pierwszym układem nośnikowym z wykorzystaniem miceli polimerowych jest Genexol PM [8].

W kompleksie obecny jest lek przeciwnowotworowy paklitaksel. Powyższa formuła ma w porównaniu do tradycyjnego paklitakselu udoskonaloną rozpuszczalność, przy ograniczeniu toksyczności.

\section{Dendrymery}

Spośród nanocząstek organicznych szczególnie dużą uwagę skupiają dendrymery. Są to struktury symetryczne, zbudowane z rdzenia, od którego odchodzą ramiona. Nazwa dendrymery pochodzi od greckich słów "dendros" i "meros"(drzewo i część), co tłumaczy ich rozgałęziony kształt (Chis i in., 
2020). Dendrymery mogą być zbudowane z różnych jednostek budulcowych - najbardziej popularne są tzw. PAMAM (poliamidoaminowe), czy PPI (polipropylenoiminowe), czy polieterowe, karbokrzemowe i peptydowe [9].

Wewnątrz dendrymerów istnieją wolne przestrzenie tzw. jamy, w których można umieszczać substancje aktywne biologicznie i w ten sposób je transportować (Kubiak, 2014). Na końcach ramion można w trakcie syntezy umieszczać różne grupy funkcyjne, co wpływa na aktywność i trwałość dendrymerów. Ponadto są to miejsca zaangażowane $\mathrm{w}$ wybiórcze działanie dendrymerów. W efekcie chemioterapeutyki mogą być dostarczane tylko do komórek nowotworowych, z pominięciem zdrowych komórek pacjenta (Błaszczak-Świątkiewicz i in., 2013). Transport za pomocą dendrymerów może odbywać się nie tylko poprzez "ładowanie" jam, ale również poprzez związanie leku z grupami na powierzchni ramion, czy wreszcie na drodze łączenia obu tych sposobów (Ryc. 4). (a)

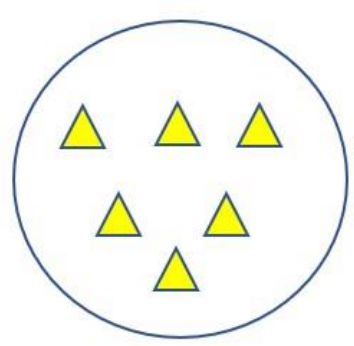

(b)

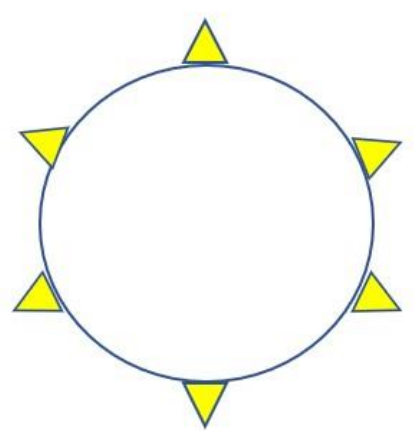

(c)

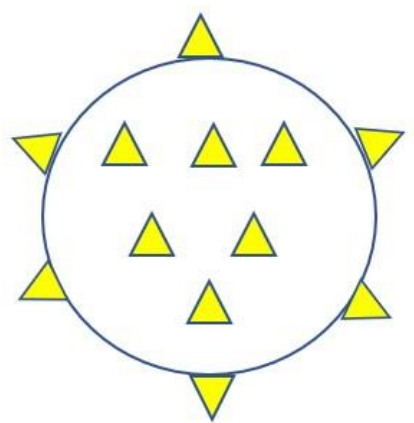

Ryc.4. Sposoby ładowania leku ( $\Delta$ ) do dendrymerów: a) enkapsulacja wnętrza, b) peryferyczne dołączenie, c) enkapsulacja wnętrza wraz z peryferycznym dołączeniem

Niezwykle ciekawe są badania prowadzone obecnie z zastosowaniem technologii DEP ${ }^{\circledR}$ (Dendrimer Drug Delivery) opracowanej przez australijską firmę biotechnologiczną Starpharma. W II fazie badań klinicznych jest DEP ${ }^{\circledR}$ docetaksel [10]. W roku 2021 Starpharma rozpoczęła współpracę z firmą farmaceutyczną Merck, prowadząc badania przedkliniczne na mysim modelu raka jajnika z zastosowaniem DEP ${ }^{\circledR}$ skoniugowanego z przeciwciałem monoklonalnym anty-Her-2, tzw. trastuzumabem (Herceptyna) [11].

Ciekawą opcją w stosowaniu dendrymerów jako nośników leków mogą stać się tzw. dendrymery samorozpadające się, SID (ang. self-immolative dendrimers). Każdy SID zbudowany jest $z$ rdzenia zwanego łącznikiem (ang. adapter), wyzwalacza (ang. trigger) oraz z reportera. Rdzeń bierze udział w przekazaniu sygnału do rozpadu cząsteczki, co dzieje się po wcześniejszym odbezpieczeniu wyzwalacza pod wpływem odpowiednich czynników (chemicznych, fizycznych lub biologicznych). W końcowej fazie dochodzi do uwolnienia reportera - transportowanego leku (Wyrębiak i in., 2019). Prawidłowo skonstruowany SID zapewnia uwalnianie substancji czynnej tylko w określonym miejscu organizmu, na przykład pod wpływem enzymu produkowanego w dużych ilościach przez komórki nowotworowe. Bardzo istotnym aspektem 
potencjalnego zastosowania SID w terapii przeciwnowotworowej jest także to, iż może być nośnikiem równocześnie kilku leków, o różnych mechanizmach działania. To umożliwiłoby ograniczenie zjawiska oporności lekowej, obserwowanej w komórkach nowotworowych po leczeniu jednym chemioterapeutykiem (Wyrębiak i in., 2019).

$\mathrm{Na}$ dzień dzisiejszy istotnym ograniczeniem w zastosowaniu dendrymerów w biomedycynie jest ich wysoka cytotoksyczność oraz immunogenność (Janaszewska i in., 2019). Wysoka immunogenność oznacza zdolność dendrymerów do indukowania odpowiedzi immunologicznej przeciwko podanemu nośnikowi leku. O immunogenności, podobnie jak cytotoksyczności dendrymerów, decyduje ich ładunek powierzchniowy. Najbardziej bezpieczne pod tym względem są dendrymery anionowe i polarne.

\section{Nanocząstki nieorganiczne metali}

\section{Nanocząstki złota}

Nanocząstki złota charakteryzują się wieloma unikalnymi właściwościami, które pozwalają na ich zastosowanie w medycynie. Wykazują one niezwykłą plastyczność, co umożliwia im nadawanie rozmaitych kształtów, a także pozwala na stosunkowo łatwe przyłączenie różnych ligandów, dzięki czemu nanocząstki mogą zostać odpowiednio "zaadresowane". Jest to możliwe np. poprzez addycję przeciwciał (Rzeszutek i in., 2014; Bai i in., 2020). Podobnie jak w przypadku nanoocząstek organicznych, nanocząstki złota nie są wolne od toksycznego oddziaływania. Toksyczność ta jest bezpośrednio związana z wielkością, kształtem i stężeniem nanocząstek, jednakże w określonym przedziale stężeń wykazują bardzo niską cytotoksyczność, co umożliwia ich zastosowanie na potrzeby medycyny (Woźniak, 2017).

Wyżej wspomniane nanostruktury mogą być wykorzystywane nie tylko jako nośniki leków, ale także w PPT (terapii fotochemicznej chorób nowotworowych). Ten sposób leczenia opiera się na promieniowaniu elektromagnetycznym, które zostaje nakierowane na nanocząstki skumulowane $w$ tkankach patologicznych (guz nowotworowy). Elementy te absorbują energię cieplną, co prowadzi do zwiększenia temperatury zmienionego nowotworowo obszaru, a następnie do śmierci komórek (Bai i in., 2020; Balcer i Mazur, 2020). Stanowi to także szansę ulepszenia stosowanych terapii, takich jak radioterapia, ponieważ nanocząstki są w stanie pochłonąć maksymalną ilość promieniowania po uprzednim umieszczeniu ich w zmienionym nowotworowo obszarze. W ostatnich latach podjęto badania kliniczne z wykorzystaniem nanocząstek złota jako nośniki leków, czy też $w$ terapii termicznej u pacjentów onkologicznych (Singh i in., 2018).

\section{Nanocząstki miedzi}

Uwagę naukowców skupiają także nanocząstki miedzi. Wykazują zdolność indukowania śmierci komórek nowotworowych. Taki efekt wykazano np. wobec komórek raka jajnika (linia HeLa) (Rzeszutek i in., 2014). Najprawdopodobniej nanocząstki te przedostają się do lizosomów i poprzez zmianę ciśnienia osmotycznego lub wytwarzając wolne rodniki, są przyczyną uwolnienia zawartości organelli do światła komórki. Wykazano również korelację między działaniem nanostruktur z tlenku miedzi a zatrzymaniem cyklu komórek nowotworowych czerniaka i HeLa, a także uszkodzeniem błon mitochondrialnych i indukowaniem śmierci apoptotycznej 
(Rzeszutek i in., 2014). W porównaniu z innymi nanocząstkami metali, takimi jak srebro, kobalt, nanocząstki miedzi charakteryzują się wyższą cytotoksycznością wobec komórek nowotworowych w niskich stężeniach, a zarazem większą stabilnością (Halevas i Pantazaki, 2018).

\section{Podsumowanie}

Nanotechnologia, choć budzi wielkie nadzieje, powoduje także wiele obaw oraz niepewności. Jak wspomniano powyżej, nanostruktury zarówno te organiczne, jak inieorganiczne wykazują działanie toksyczne. Główne zagrożenie powodowane przez nanocząstki związane jest $z$ ich przenikaniem nie tylko do komórek chorych, ale także zdrowych. Na obecny moment ciągle mało jest informacji oraz badań analizujących toksyczność nanocząstek szczególnie in vivo, podobnie jak regulacji prawnych związanych z wykorzystaniem oraz produkcją układów nanonośnikowych (Dębek i in., 2017). Jedynym rozwiązaniem jest czas i intensyfikacja badań, co pozwoli na pozyskanie większej ilości danych. Należy mieć nadzieję, że podobnie jak terapia CART stała się rzeczywistością, tak i narzędzia nanotochenologii w niedalekiej przyszłości będą mogły być stosowane bezpiecznie, po wyeliminowaniu lub zminimalizowaniu ich niedoskonałości.

\section{Literatura:}

Bai, Xu., Wang, Y., Song, Z., Feng, Y. et al. 2020. The Basic Properties of Gold Nanoparticles and their Applications in Tumor Diagnosis and Treatment. International Journal of Molecular Sciences 21, 2480; doi:10.3390/ijms21072480.

Balcer, E., Mazur, M. 2020. Nanocząstki złota w diagnostyce i terapii nowotworów - wy- brane zastosowania. BIULETYN Wydziatu Farmaceutycznego Warszawskiego Uniwersytetu Medycznego 1, 1-9; http://biuletynfarmacji.wum.edu.pl/.

Bayda, S., Adeel, M., Tuccinardi, T., Cordani, M. 2020. The History of Nanoscience and Nanotechnology: From Chemical-Physical Applications to Nanomedicine. Molecules 25, 112; doi:10.3390/molecules25010112.

Beatty G.L., Gladney W. L., 2015. Immune escape mechanisms as a guide for cancer immunotherapy. Clinical Cancer Research, 21 (4), 687-692.

Błaszczak-Świątkiewicz, K., Olszewska, P., Mikiciuk-Olasik, E. 2013. Zastosowanie nanocząsteczek w leczeniu i diagnostyce nowotworów. NOWOTWORY Journal of Oncology, volume 63, number 4, 320330; DOI: $10.5603 / \mathrm{NJO} .2013 .0020$.

Chis, A., Dobrea, C., Morgoyan, C., Arseniu, A. et al. 2020. Applications and Limitations of Dendrimers in Biomedicine. Molecules 25, 3982; doi:10.3390/molecules25173982.

Dębek, P., Feliczak-Guzik, A., Nowak, I. 2017. Nanostruktury - ogólne informacje. Zastosowanie nanoobiektów w medycynie i kosmetologii. Postępy Higieny i Medycyny Doświadczalnej 71, 1055-1062.

Dytfeld, D., Łojko-Dankowska, A., Matuszak, M., Wache, A., et al., 2020. Road to clinical implementation of CAR-T technology in Poznań. Acta Haematologica Polonica 51 (1), 24-28.

Dzieńdziura, K. 2021. Immunoterapia nowotworów z wykorzystaniem genetycznie modyfikowanych limfocytów T (CAR T-cell therapy). Praca licencjacka wykonana w Zakładzie Genetyki Wydziału Biologii UAM w Poznaniu.

Gil, L., Łojko-Dankowska, A., Matuszak, M., Wache, A., et al., 2020. CAR-T cell therapy toxicity and its management. Acta Haematologica Polonica 51 (1), 6-10.

Halevas, EG., Pantazaki, AA. 2018. Copper Nanoparticles as Therapeutic Anticancer 
Agents. Nanomedicine and Nanotechnology Journal 2(1):119.

Janaszewska, A., Lazniewska, J., Trzepiński, P. et al. 2019. Cytotoxicity of dendrimers. Biomolecules 2019, 9, 330;

doi:10.3390/biom9080330

Kim, DW., Cho, JY., 2020. Recent advances in allogenic CAR-T cells. Biomolecules 10, 263 doi:10.3390/biom10020263.

Knopik-Skrocka, A., Kręplewska, P., JarmołowskaJurczyszyn, D., 2017. Tumor blood vessels and vasculogenic mimicry - current knowledge and searching for new cellular/molecular targets of anti-angiogenic therapy. Advances in Cell Biology, 5 (1), 50-71.

Marofi, F., Motavalli, R., Safonov, VA., et al., 2021. CAR-T cells in solid tumors: challenges and opportunities. Stem Cell Research \& Therapy. 12, 81

https://doi.org/10.1186/s13287-02002128-1.

Rodriguez-Garcia, A., Palazon, A., Noguera-Ortega, E. et al. 2020. CAR-T Cells Hit the Tumor Microenvironment: Strategies to Overcome Tumor Escape. Frontiers in Immunology 11, 1109 https://doi.org/10.3389/fimmu.2020.0110 9

Rzeszutek, J., Matysiak, M., Czajka, M., Sawicki, K. et al. 2014. Zastosowanie nanocząstek i nanomateriałów w medycynie. Hygeia Public Health 49 (3), 449-457.

Sen, K., Mandal, M. 2013. Second generation liposomal cancer therapeutics: Transition from laboratory to clinic. International Journal of Pharmaceutics 448, 28- 43.

Singh, P., Pandit, S., Mokkapati, V., Garg, A. et al. 2018. Gold Nanoparticles in Diagnostics and Therapeutics for Human Cancer. International Journal of Molecular Sciences. 19, 1979; doi:10.3390/ijms19071979.

Styczyński, J., 2020. A brief history of CAR-T cells: from laboratory to the bedside. Acta Haematologica Polonica 51 (1), 2-5.

Szymanowski, W., Gornowicz, A., Bielawska, A., Bielawski, K., 2020. Zastosowanie nano- technologii w immunoterapii nowotworów. Postępy Higieny Medycyny Doświadczalnej 74, 131-143.

Tahmasebi, S., Elahi, R., Esmaeilzadeh, A., 2019. Solid tumors challenges and new insight of CAR-T cell engineering. Stem Cell Reviews and Reports 15, 619-636.

Woźniak, A., Malankowska, A., Nowaczyk, G., Grześkowiak, B. et al. 2017. Size and shape-dependent cytotoxicity profile of gold nanoparticles for biomedical applications. Journal of Materials Science: Materials in Medicine, 28:92. DOI 10.1007/s10856-017-5902-y.

Wyrębiak, R., Olędzka, E., Sobczak, M. 2019. Dendrymery domino jako innowacyjne nośniki substancji Leczniczych. POLIMERY 64, nr 3, 163-172; DOI: dx.doi.org/10.14314/polimery.2019.3.1.

\section{Źródła internetowe:}

[1] https://gco.iarc.fr/today/home (dostęp 28.08.2021)

[2] http://onkologia.org.pl/wp-content/uploads/Nowotwory_2017.pdf (dostęp 28.08. 2021)

[3] www.stream.wum.edu.pl/pl/baza-wiedzy/70immunoterapia-nowotworow (dostęp 28.08. 2021)

[4] https://pulsmedycyny.pl/czy-stac-nas-na-niewdrazanie-nowych-technologii-978003 (dostęp 28.08. 2021)

[5] https://pulsmedycyny.pl/abm-100-m|n-zltrafi-na-finansowanie-badan-nad-terapia-onkologiczna-995879 (dostęp 28.08. 2021)

[6] https://abm.gov.pl/pl/aktualnosci/709,Wyniki-konkursu-na-opracowanie-polskiejterapii-adoptywnej-CARCAR-T.html (dostęp 28.08.2021)

[7] https://www.termedia.pl/Konferencja-12THInternational-Conference-Of-Contemporary-Intro,1437,12757.html\# (dostęp 28.08.2021)

[8] https://samyangbiopharm.com/eng/ProductIntroduce/injection01 (dostęp 28.08.2021) 
[9] https://biotechnologia.pl/biotechnologia/dendrymery-niezwykle-molekulywykorzystywane-jako-transportery-lekow,18347 (dostęp 28.08.2021)

[10] https://starpharma.com/drug_delivery (dostęp 28.08.2021)

[11] https://www.adcreview.com/news/msd-andstarpharma-sign-research-agreement/ (dostęp 28.08.2021)

\section{Notki o Autorach:}

Jowita Kwiatkowska - studentka I roku studiów licencjackich na Wydziale Biologii oraz studentka III roku studiów licencjackich na Wydziale Chemii Uniwersytetu im. Adama Mickiewicza w Poznaniu, w przyszłości, być może niedalekiej, także studentka medycyny; zainteresowania naukowe oscylują głównie wokół zagadnień związanych z medycyną, chemią i biotechnologią (innowacyjne wykorzystywanie związków chemicznych i nanocząstek w terapiach chorób nowotworowych, genetycznych, a także autoimmunologicznych).
Piotr Wawrzyniak - student I roku studiów licencjackich na Wydziale Biologii Uniwersytetu im. Adama Mickiewicza w Poznaniu; zainteresowania naukowe skupiają się głównie na wirusologii i immunologii, a także na sposobach walki z nowotworami.

Agnieszka Knopik-Skrocka - dr, Prof. UAM, nauczyciel akademicki, akredytowany praktyk tutoringu, członek Rady Tutorów na Wydziale Biologii, opiekun naukowy sekcji studenckiej Badań Nowotworów Koła Naukowego Przyrodników

Artykuł w dużej mierze stanowi efekt procesu tutorskiego, zrealizowanego przez Panią Jowitę Kwiatkowską pod opieką dr, Prof. UAM Agnieszki Knopik-Skrockiej w roku akadem. 2020-21. Ze względu na tematykę artykułu do pracy nad nim włączył się także Pan Piotr Wawrzyniak zafascynowany obecnymi możliwościami biologii, biotechnologii i chemii w opracowaniu nowoczesnych strategii terapeutycznych. 